Original Contribution

\title{
EFFECT OF SALICYLIC ACID AND ALOE VERA GEL ON POSTHARVEST QUALITY OF TABLE GRAPES (VITIS VINIFERA)
}

\author{
H. Peyro ${ }^{1 *}$, S. Abbas Mirjalili ${ }^{2}$, B. Kavoosi ${ }^{3}$ \\ ${ }^{1}$ Department of Horticulture, Science and Research Branch, Islamic Azad University, \\ Tehran, Iran \\ ${ }^{2}$ Agricultural Jahad Institiute of Technical and Vocational Higher Education, Education \\ and Extension Organisation, Tehran, Iran \\ ${ }^{3}$ Horticulture Crop Research Department, Fars Agricultural Research and Natural \\ Resource and education Center, AREEO, Shiraz, Iran
}

\begin{abstract}
To investigate the effects of salicylic acid dipping and Aloe vera gel coating on shelf life and post harvest quality of table grapes (Vitis vinifera) of the cultivar Shahroudi, a factorial experiment was conducted on the basis of randomized complete blocks design with three factors and three replicates in agricultural faculty of Islamic Azad University in 2014. The treatments were dipping in Salicylic acid (three levels of 0,1 and 2 mmmol-1 for 15 minutes) and coating with Aloe vera gel (four levels of 0 , $10 \%, 15 \%$ and $20 \% \mathrm{w} / \mathrm{v}$ ) and measurement of traits in 1st day, 30th day and 60th day after treatment of berries. The results showed that the interaction effect of salicylic acid and Aloe vera gel application was significant on all of traits except for $\mathrm{pH}$ value in a way that the best and the minimum weight loss $(0.09 \mathrm{~g})$ was obtained by application of $2 \mathrm{mmol}^{-1}$ Salicylic acid and $20 \%$ Aloe vera gel in $1^{\text {st }}$ day after treatment. The greatest amount of total soluble solids (428.43 g. $100 \mathrm{~g}^{-1}$ fruit juice) was found in $2 \mathrm{mmol}^{-}$ ${ }^{1}$ Salicylic acid and $15 \%$ Aloe vera gel in $60^{\text {th }}$ day. The highest Catalase enzyme activity (0.0013 Ua.mg ${ }^{1}$ Pro) was attained in $2 \mathrm{mmol}^{-1}$ Salicylic acid and $15 \%$ Aloe vera gel in $30^{\text {th }}$ day. These results demonstrated that treatment of grape berries by salicylic acid and Aloe vera gel had positive effect on shelf life of table grapes and their postharvest quality.
\end{abstract}

Key words: Aloe vera gel, Salicylic Acid, shelf life and post harvest quality, table grapes (Vitis vinifera)

\section{INTRODUCTION}

Grape (Vitis vinifera) is one of the most economically important plant species due to its diverse uses in production of wine, grape juice and other food products (1). It is cultivated in all continents in the temperate regions where sufficient rain, warm and dry summers as well as relatively mild winters are normal climatic patterns (2). The grape has been used in folk medicine for its biological activities since ancient times. The leaves of the plant, which have astringent and haemostatic properties, are used in the treatment of diarrhea, hemorrhage, varicose veins, hemorrhoids, inflammatory disorder, pain, hepatitis, and free radical related diseases and externally for centuries in Anatolia to heal wounds and drain furuncles (3-5).

\footnotetext{
*Correspondence to: Hossein Peyro, No. 4, Bahonar 6, Bahonar Blvd. Yasuj. Kohgiluye and Boyerahmad, Iran, P.O.Box: 75919-54479, Iran, Tel: +98-74-33220286, Fax: +98-74-33228910 Email: Hossein.peyro@gmail.com
}

Unfortunately, table grapes show severe problems during postharvest storage and retailing. The losses of quality are based on weight loss, color changes, accelerated softening and rachis browning, and high incidence of berry decay (6), which lead to a reduction of shelf life. SA is considered as a plant hormone (7), inhibiting ethylene biosynthesis and delaying the fruit senescence (8). The involvement of SAin systemic acquired resistance, associated with the production of pathogenesis-related proteins, has been extensively reported (9). It has been reported that SA application either pre-harvest or postharvest reduced fungal decay in sweet cherry $(10,11)$, strawberry $(12,13)$ and peach fruits (14) through induction of the defense resistance system and stimulation of antioxidant enzymes. Aloe vera has medicinal properties is a tropical and subtropical plant that has been used from ancient time (15). The gel of Aloe vera leaves is the colorless mucilaginous, obtained from the 
parenchymatous cells. Application of Aloe vera gel in the food industry is increasing day by day as resource of drinks, beverages and ice creams (15). Aloe vera gel is also used in the cosmetic industry, including treatment of burns and scars and in wound healing (16). The antifungal activity of Aloe vera gel was observed against several pathogenic fungi including Botrytis cinerea, main causative agent to decay grape fruit $(17,18)$.

Therefore, the present study was conducted to investigate the effect of BRs on physicochemical properties of berries and its effect on postharvest life during low temperature storage of grape cv. Flame Seedless.

\section{MATERIALS AND METHODS}

To investigate the effects of salicylic acid dipping and Aloe vera gel coating on shelf life and post harvest quality of table grapes (Vitis vinifera) of the cultivar Shahroudi, a factorial experiment was conducted on the basis of randomized complete blocks design with three factors and three replicates in agricultural faculty of Islamic Azad University in 2014. Table grapes (Vitis vinifera) of the cultivar Shahroudi were harvested at the ripe stage from a commercial vineyard in North Yasuj, Iran. The harvest time was determined by the total soluble solids concentration (TSS), which was $19.5 \%$ (TSS for the Shahroudi cultivar ranges between $18 \%$ and $20 \%$ at the ripe stage). Fruits were selected for size and color uniformity. Blemished, damaged, or diseased berries were discarded carefully. After preparation, fruits were weighed to about $1 \mathrm{~kg}$ and 3 clusters. The treatments were dipping in Salicylic acid (three levels of 0,1 and 2 mmmol-1 for 15 minutes)(C) and coating with Aloe vera gel (four levels of $0,10 \%, 15 \%$ and $20 \% \mathrm{w} / \mathrm{v}$ ) (A) and measurement of traits in $1 \mathrm{st}$ day, 30th day and 60th day after treatment of berries. Selected clusters of 15-20 grapes were Dipped and coated in the mentioned treatments for 5 minutes. Afterwards, they were hung up and dried at room temperature $(65-70 \%)$ for $2-$ 3 hours and then stored in plastic boxes at $10 \pm 2^{\circ} \mathrm{C},(70-75 \% \mathrm{RH})$. The quality of these stored fruits was determined by analyzing the parameters at 0 day and then after at regular interval of 30 days. All the analyses were performed without removing coating from their surface.

Data were statistically analysed using one-way analysis of variance (ANOVA) with SAS statistical software (SAS 9.1; SAS Institute); mean comparisons were carried out by Duncan's multiple range test.
Weight Loss Percentage (WLP):

Weight loss was expressed as the percentage loss of the initial total weight calculated by considering the difference between initial weight and final weight of presently tested grapes divided by their initial weight. Berry firmness was measured using a Texture Analyzer (TA+HDi ${ }^{\circledR}$ Stable Micro Systems, UK) equipped with a HDP/90 platform and 5 $\mathrm{kg}$ load cell. The measurement was made on the equatorial position of the berry with $4 \mathrm{~mm}$ probe at a test speed of $1 \mathrm{~mm} / \mathrm{s}$ to a constant compression distance of $1 \mathrm{~mm}$. The readings were expressed as maximum force in grams (19).

\section{Measurement of total soluble solids (TSS)}

50 berries from each replicate were squeezed and the juice obtained was filtered through a cheese cloth.Total soluble solids (TSS) was measured by a temperature compensated digital refracto meter (Atago PAL-1, model 3810, Japan) and expressed as oBrix. Titratable acidity (TA) was determined as per AOAC (2005) and expressed as grams of tartaric acid equivalents per $100 \mathrm{ml}$ of juice. The $\mathrm{pH}$ of the juice was measured using a glass electrode $\mathrm{pH}$ meter model Crison Micro pH 2000 (Crison Instruments, S.A., Barcelona, Spain). The $\mathrm{pH}$ meter was calibrated with buffer at $\mathrm{pH} 4.0$ and 7.0 before being used.

\section{Determination of Catalase (CAT) activity}

Activity of catalase enzyme was performed in approximately $1 \mathrm{~g}$ of leaf tissue homogenized in $10 \mathrm{~mL}$ of $50 \mathrm{mM}$ Na-phosphate buffer, $\mathrm{pH}$ 7.8 plus $1 \%$ PVP-40. The suspension was filtered through four layers of cheese cloth, followed by centrifugation at $17,000 \times \mathrm{g}$, at 4 ${ }^{\circ} \mathrm{C}$ for $30 \mathrm{~min}$. The reaction was performed in $0.85 \mathrm{~mL}$ of $50 \mathrm{mM}$ Na-phosphate buffer, $\mathrm{pH}$ $7.8,0.5 \mathrm{~mL}$ of $30 \mathrm{mM} \mathrm{H} 2 \mathrm{O} 2$ and $0.15 \mathrm{~mL}$ of extract (20). Decomposition of $\mathrm{H} 2 \mathrm{O} 2$ was started by addition of extract following the changes in absorbance in a spectrophotometer at $240 \mathrm{~nm}$ for 2.5 minutes at $25{ }^{\circ} \mathrm{C}$. The enzyme activity was expressed in absorbance units (AU) min-1 mg-1 of protein.

\section{Determination of peroxidase (POD) activity} POD enzyme (EC. 1.11.1.7) activity of the two Gerbera cultivars was studied using the Hemeda and Kellin (1990) method (21). In this method, after emitting the samples from $80{ }^{\circ} \mathrm{C}, 0.5 \mathrm{~g}$ stem texture was pulverized in liquid nitrogen. After transferring the samples to the falcon, $50 \mathrm{mg}$ polyvinyl pyrrolidone (Merck, Germany) and $3 \mathrm{ml}$ potassium phosphate (100 mM, pH 7) were added to each sample; these were then centrifuged at $4^{\circ} \mathrm{C}$ and $10,000 \mathrm{rpm}$ for $30 \mathrm{~min}$. $70 \mu \mathrm{L}$ of the 
PEYRO H., et al.

supernatant was then mixed with $750 \mu \mathrm{L}$ guaiacol, $750 \mu \mathrm{L}$ phosphate buffer $(0.01 \mathrm{M})$, $1400 \mu \mathrm{L}$ distilled water and the samples' absorption at $470 \mathrm{~nm}$ were recorded.

\section{RESULTS}

According to results of variance analysis, interaction effects of Salicylic acid dipping
(C), Aloe vera gel coating (A) application and measuring times was significant $(\mathrm{P}<0.05)$ on measured traits of weight loss, Berry firmness, Total soluble solids (TSS), Titrable acidity (TA), Catalase enzyme activity (CAT), Peroxidase enzyme activity (POD), except for pH value. (Table 1)

Table 1. Analysis of variance for measured traits in table grapes (Vitis vinifera) of the cultivar Shahroudi treated by different levels of Salicylic acid Aloe vear gel in different measuring days after treatment

\begin{tabular}{rrccccccc}
\hline \multirow{2}{*}{ S.O.V } & D & \multicolumn{7}{c}{ Mean Squares } \\
\cline { 3 - 10 } & F & $\begin{array}{c}\text { Weight } \\
\text { Loss }\end{array}$ & $\begin{array}{c}\text { Berry } \\
\text { Firmness }\end{array}$ & TSS & TA & pH & CAT & POD \\
\hline C & 2 & $0.121^{*}$ & $37.33^{*}$ & $299.99^{*}$ & $0.0025^{*}$ & $0.093^{\mathrm{ns}}$ & $3.84^{*}$ & $4.05^{*}$ \\
$\mathrm{~A}$ & 3 & $0.142^{*}$ & $35.99^{*}$ & $501.99^{*}$ & $0.0021^{*}$ & $0.171^{\mathrm{ns}}$ & $2.04^{*}$ & $3.16^{*}$ \\
$\mathrm{~T}$ & 2 & $0.119^{\mathrm{ns}}$ & $29.33^{\mathrm{ns}}$ & $255.89^{*}$ & $0.0011^{\mathrm{ns}}$ & $0.049^{\mathrm{ns}}$ & $1.45^{*}$ & $1.13^{*}$ \\
$\mathrm{SA} \times \mathrm{A}$ & 6 & $0.171^{*}$ & $38.45^{*}$ & $521.28^{*}$ & $0.0048^{*}$ & $0.089^{\mathrm{ns}}$ & $2.34^{*}$ & $1.32^{*}$ \\
$\mathrm{SA} \times \mathrm{T}$ & 4 & $0.145^{*}$ & $42.22^{*}$ & $328.23^{*}$ & $0.0039^{*}$ & $0.078^{\mathrm{ns}}$ & $1.89^{*}$ & $1.63^{*}$ \\
$\mathrm{~A} \times \mathrm{T}$ & 6 & $0.156^{*}$ & $31.54^{*}$ & $285.25^{*}$ & $0.0051^{*}$ & $0.088^{\mathrm{ns}}$ & $2.71^{*}$ & $4.19^{*}$ \\
$\mathrm{SA} \times \mathrm{A} \times \mathrm{T}$ & 12 & $0.190^{*}$ & $48.32^{*}$ & $423.22^{*}$ & $0.0059^{*}$ & $0.079^{\mathrm{ns}}$ & $1.09^{*}$ & $5.26^{*}$ \\
\hline
\end{tabular}

$*, * *$, ns shows significant in $5 \%, 1 \%$, and insignificant ,respectively

Concerning the mean comparison, the best and minimum weight loss $(0.09 \mathrm{~g})$ was obtained by application of $2 \mathrm{mmol}^{-1}$ Salicylic acid and $20 \%$ Aloe vera gel in $1^{\text {st }}$ day after treatment. However, the maximim weight loss was observed in control treatments and $60^{\text {th }}$ day (Figure 1). The highest berry firmness (17.91 g.force ${ }^{-1}$ ) was evident in the treatment of 1 $\mathrm{mmol}^{-1}$ Salicylic acid and 20\% Aloe vera gel in $1^{\text {st }}$ day and the least with control treatments in $60^{\text {th }}$ day (Figure 2). The results indicated that the greatest amount of total soluble solids (428.43 g. $100 \mathrm{~g}^{-1}$ fruit juice) was found in 2 $\mathrm{mmol}^{-1}$ Salicylic acid and $15 \%$ Aloe vera gel in $60^{\text {th }}$ day and the lowest amount in control treatments and 30 $0^{\text {th }}$ day (Figure 3). Titrable acidity showed the maximum $\left(0.712\right.$ g.ml $\left.{ }^{-1}\right)$ and minimum value in $1 \mathrm{mmol}^{-1}$ Salicylic acid $15 \%$ Aloe vera gel in $30^{\text {th }}$ day and control treatments in $60^{\text {th }}$ day, respectively (Figure 4). According to results of mean comparison, the highest Catalase enzyme activity $(0.0013$ Ua.mg ${ }^{-1}$ Pro) was attained in $2 \mathrm{mmol}^{-1}$ Salicylic acid and $15 \%$ Aloe vera gel in $30^{\text {th }}$ day, while the lowest of that was reported in control treatments and $1^{\text {st }}$ day (Figure 5). The greatest peroxidase enzyme activity (0.00182 Ua.mg${ }^{1}$ Pro) was observed in $2 \mathrm{mmol}^{-1}$ Salicylic acid and $10 \%$ Aloe vera gel in $30^{\text {th }}$ day and the least activity in control treatments and $1^{\text {st }}$ day (Figure 6).
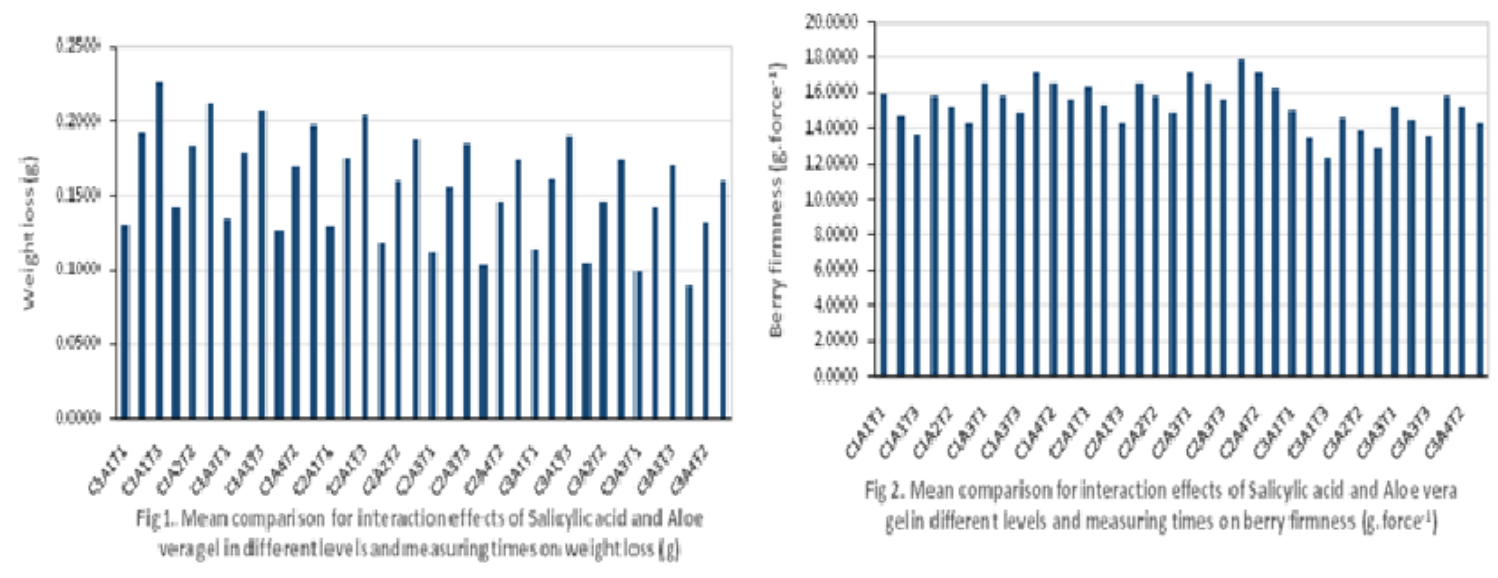

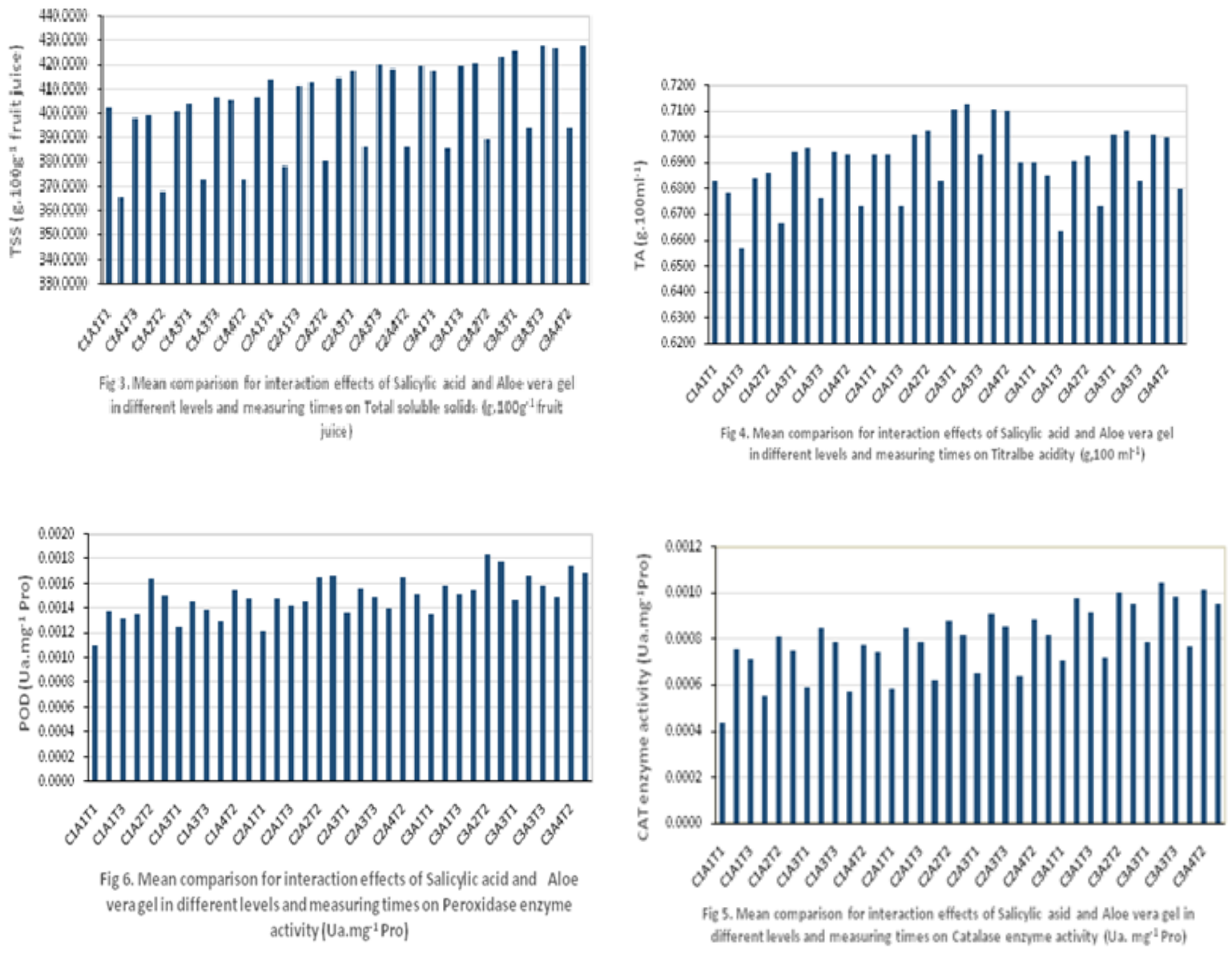

\section{DISCUSSION}

The results showed that the dipping in Salicylic acid and coating with Aloe vera in different measurement days had positive effect on the postharvest quality table grapes (Vitis vinifera) of the cultivar Shahroudi and improved the traits of the weight loss, berry firmness, total soluble solids, titrable acidity, Catalase enzyme activity and peroxidase enzyme activity.

Dipping table grapes in $2 \mathrm{mmol}^{-1}$ Salicylic acid and $20 \%$ Aloe vera gel in $1^{\text {st }}$ day after treatment had positive effect on weight loss and decreased it to the lowest level. These results are according to results of Bagheri et al., 2015 researches on persimmon fruits (22). SA and Aloe vera treatments may be are effective in maintaining membrane integrity and lower rate of weight loss. The berries firmness increased in the treatment of $1 \mathrm{mmol}^{-1}$ Salicylic acid and $20 \%$ Aloe vera gel at 1 st day after treatment. These results are in agreement with results of Ranjbaran et al., 2011 on table grapes with application of Salicylic acid (23). The effect of Softening is an important part of the ripening process in most fruit and it is widely recognized that changes in cell walls accompany fruit softening. During the ripening process, the progressive loss of firmness is the result of a gradual transformation of protopectin into pectin which is degraded by

the enzyme, polygalacturonase, in the cell wall (24). This could be explained that in fruits SA delays fruit softening by affecting major cell wall degrading enzymes activity such as cellulase, polygalacturonase and xylanase (25) through the reduction of ethylene production. It may be concluded that there is a close relation between water loss and berry firmness during storage. Application of 2 mmol-1 Salicylic acid and 15\% Aloe vera gel in 60th day increased the content of total soluble solids to the highest level of 428.43 g. $100 \mathrm{~g}-1$ fruit juice.

These results are similar to Shirzadeh et al. (2011) researches (26). Total soluble solids may augment during fruit ripening because of the action of sucrose-phosphate synthase (SPS), a key enzyme in sucrose biosynthesis. The enzyme activity is under the influence of ethylene and the ripening process itself during storage. The authors suggested that MeSA reduced ethylene production and this may cause decrease in SPS enzyme activity leading to decrease in sucrose synthesis (27).The use of an edible coating based on A. vera gel as a postharvest treatment to maintain sweet cherry (28) and nectarine (29) quality and safety was reported. Aloe vera gel, used as an edible coating in fruit, would be an innovative and interesting means for commercial application and an alternative to the use of postharvest 
chemical treatments (30). This may be because of modified atmospheric conditions created by Aloe vera gel coating and decrease of respiration and eventually catabolism of soluble solids (31). The highest amount of titrable acidity was recorded in 1 mmol-1 Salicylic acid $15 \%$ Aloe vera gel in 30th day. The results of this study are in line with results of Zafari et al., (2015) on strawberry fruits by application of exogenous putrescine and Aloe vera gel coating (32). The Aloe vera gel works as a barrier to $\mathrm{O} 2$ and $\mathrm{CO} 2$ and acts as moisture barrier, and thus reduces weight loss, browning, softening, and growth of yeast and molds. The material contains antimicrobial compounds and thus prevents decay (33). The highest activity of Catalase enzyme was evident in $2 \mathrm{mmol}^{-1}$ Salicylic acid and $15 \%$ Aloe vera gel in $30^{\text {th }}$ day in comparison to treatment. These results are in accordance with Asghari et al. (2013) on vitis vinifera L.cv. Gizel Uzum (27). Application of $2 \mathrm{mmol}^{-1}$ Salicylic acid and $10 \%$ Aloe vera gel in $30^{\text {th }}$ day caused the highest level of peroxidase enzyme activity. At the onset of fruit ripening and senescence as oxidative phenomena the activities of oxygen detoxifying enzyme such as catalase decreases while the superoxide or hydrogen peroxide enzymes increase to toxic levels (34). The balance between superoxide dismutase (SOD), POD and catalase (CAT) activities in cells is necessary for determining the steady-state level of $\mathrm{O} 2$-and $\mathrm{H}_{2} \mathrm{O}_{2}$. SA interaction with the above mentioned enzymes leads to high levels of $\mathrm{H}_{2} \mathrm{O}_{2}$ accumulating in cells, which induces fruit resistance against pathogens via activating protective enzymes and PR-proteins $(35,36)$. Retardation of POD activity by of SA treatment has also been reported for loquat (37).

\section{CONCLUSION}

In this study, dipping in Salicylic acid and coating with Aloe vera gel in different measurement days improved the postharvest quality of table grapes (Vitis vinifera) of the cultivar Shahroudi due to maintaining membrane integrity and lower rate of weight loss.

\section{ACKNOWLEDGEMENT}

The research was funded by Hotriculture Department of Islamic Azad University, branch of Sciences and Researches in Tehran.

\section{REFERENCES}

1. Ali, K., Maltese, F., Choi, Y., Verpoorte, R. Metabolic constituents of grapevine and grape-derived products. Phytochem. Rev; 9:357-378. doi: 10.1007/s11101-009-9158-
PEYRO H., et al. 0. [PMC free article] [PubMed] [Cross Ref]. 2010.

2.Vivier, MA. Pretorius I.S. Genetic improvement of grapevine: Tailoring grape varieties for the third millennium-A review. S. Afr. J. Enol. Vitic. 21:5-26. 2000.

3. Lardos, A., Kreuter, MH. Red vine leaf. In: Kreuter, M.H. (Ed.). Phytopharm. and Phytochem. Products. Flachsmann AG. Zurich; pp. 1-7. 2000.

4.Bombardelli, E., Morazzonni, P. Vitis vinifera L. Fitoterapia. 66: 291-317, 1995.

5. Baytop, T., Bitkiler, IT. 2. Baskı. Nobel Tip Kitabevleri. İstanbul; pp. 357-358. 1999.

6. Crisosto, CH., Garner, D., Crisosto, G. Carbon Dioxide-enriched Atmospheres during Cold Storage Limit Losses from Botrytis but Accelerate Rachi Browning of 'Redglobe' Table Grapes. Postharvest Biol. Technol., 11: 181-189. 2002.

7. Raskin, I. Salicylate, a new plant hormone. Plant Physiol. 99: 799-803. 1992.

8. Khademi, Z., Ershadi, A. Postharvest application of Salicylic acid improves storability of Peach (Prunus persica cv. Elberta) fruits. International Journal of Agriculture and Crop Sciences. 5(6), 651655. 2013.

9. Beckers, GJM., and Spoel, SH. Fine-tuning plant defense signaling: salicylate versus jasmonate.Plant Biol. 8: 1-10. 2006.

10.Yao, H., Tian, S. Effects of pre- and postharvest application of salicylic acid or methyl jasmonate on inducing disease resistance of sweet cherry fruit in storage. Postharvest Biol. Technol. 35:253-262. 2005.

11.Xu, X., Tian, S. Salicylic acid alleviated pathogen-induced oxidative stress in harvested sweet cherry fruit. Postharvest Biol. Technol. 49: 379- 385. 2008.

12.Babalar, M., Asghari, M., Talaei, A., Khosroshahi, A. Effect of pre- and postharvest salicylic acid treatment on ethylene production, fungal decay and overall quality of Selvia strawberry fruit. Food Chem. 105:449-453. 2007.

13.Shafiee, M., Taghavi, TS., Babalar, M. Addition of salicylic acid to nutrient solution combined with post harvest treatments (hot water, salicylic acid, and calcium dipping) improved postharvest fruit quality of strawberry. Sci. Hort. 124: 40-45. 2010.

14.Wang, L., Chen, S., Kong, W., Li, S. Salicylic acid pretreatment alleviates chilling injury and affects the antioxidant system and heat shock proteins of peaches 
during cold storage" Postharvest Biol. Technol. 41:244-251. 2006.

15.Eshun, K., He, Q. Aloe Vera: a valuable ingredient for the food, pharmaceutical and cosmetic industries: a review. Crit. Rev. Food. Sci. Nutr. 44, 91-96. 2004.

16.Aburjai, T., Natsheh, FM. Plants used in cosmetics. Phytother. Res. 17, 987- 1000. 2003.

17. Jasso de Rodiguez, DJ Herna ndez-castillo, D.J., Rodriguez Garcia, R., Angulosanchez. J.L. Antifungal activity in vitro of Aloe Vera pulp and liquid fraction against plant pathogenic fungi. ind. Crop prod., 21, 8187. 2005.

18.Saks, Y., Barkai-Golan, R. Aloe vera gel activity against plant pathogenic fungi, post harvest Biol. Technol 6: 159- 165. 1995.

19.Rolle, L., Simone, G., Vincenzo, G. and Vittorino, N. Comparative study of texture properties characteristics and chemical of 10 white table-grape varieties. Am. J. Enol. Vitic., 62, 49 - 56. 2011.

20.Aebi, HU. Catalase; in Methods in enzymatic analysis (ed) Bergmeyer HU (New York: Academic Press) 3:276-286. 1983.

21.Hemeda, HM., Kelin, BP.. Effects of Naturally Occurring Antioxidants on Peroxidase Activity of Vegetable Extracts. J. Food Sci. 36(9): 877-880. 1990.

22. Bagheri, M., Esna-Ashari, M., Ershadi, A. Effect of postharvest calciul chloride treatment on storage life and quality of persimmon fruits (Diospyros kaki Thunb.) cv. 'Karaj'. International of Horticultural Science and Technology. 2(1): pp: 15-26. 2015.

23. Ranjbaran, E., Sarikhani, H., Wakana, A., Bakhshi, D. Effect of Salicylic acid on storage life and postharvest quality of Grape (Vitis vinifera L. cv. Bidaneh Sefid). J. Fac. Agr., Kyushu Univ., 56 (2): 263269. 2011.

24.Hobson, GE. Cellulase activity during the maturation of ripening tomato fruit. Journal of Food Science 33, 588-591. 1968.

25. Srivastava, M K., Dwivedi, UN. Ripening of banana fruit by salicylic acid. Plant Sci., 158: 87-96. 2000.

26. Shirzadeh, E., Rabiei, V., Sharafi, Y. Effect of Calcium Chloride $(\mathrm{CaCl} 2)$ on Postharvest Quality of Apple Fruits. Afr. J. Agr. Res. 6(22):5139-5143. 2011.
27.Asghari, M., Soleimani- Aghdam, M. Impact of salicylic acid on post-harvest physiology of horticultural crops. Trends in Food Science \& Technology, 21: 509. 2010.

28.Martínez-Romero, D., Alburquerque, N., Valverde, JM., Guillén, F., Castillo, S., Valero, D., Serrano, M. Postharvest sweet cherry quality and safety maintenance by Aloe vera treatment: a new edible coating, Postharvest Biol. Tecnol. 39: 93-100. 2006.

29.Ahmed, MJ., Singh, Z., Khan, AS., Postharvest Aloe vera gel-coating modulates fruit ripening and quality of 'Arctic Snow' nectarine kept in ambient and cold storage, Int. J. Food Sci. Technol. 44 1024-1033. 2009.

30.Mario, AG., Marisabel, V., Raul, D., Silvia, F., Alicia, C. Effects of Aloe vera coating on postharvest quality of tomato. Fruits. 69: 117-126. 2014.

31. Ergun, M., Satici, F. Use of Aloe vera gel as blopreservantive for 'Granny Smith' and 'red Chief' appels. The Journal of Animal \& Plant Sciences, 22: 363-368. 2012.

32. Zafari, E., Mohammadkhani, A., Roohi, V., Fadaei, A., Zafari, H. Effect of exogenous putrescine and Aloe Vera gel coating on post-harvest life of strawberry (Fragaria ananassa Duch.) fruit, cultivar Kamarosa. International Journal of Agriculture and Crop Sciences. 8(4): 578-584. 2015.

33. Valuerde, JM., Valero, A., MartinezRomero, D., Guileen, F., Castillo, S. Novel edible coating based on Aloe vera gel to maintain table grape quality and safety, $J$. Agric. Food Chem 53, 7807-7813. 2005.

34. Bowler, C., Van Montagu, M. and Inze, D. Superoxide dismutase and stress tolerance. Annu. Rev. Plant Physiol. Plant Mol. Biol., 43: 83-116.1992.

35. Klessig DF, Malamy J. The salicylic acid signal in plants.Plant Molecular Biology, 26, 1439e1458.1994.

36. Asghari M, Ahadi L. and Riaie S. Effect of salicylic acid and edible coating based Aloe vera gel treatment on storage life and postharvest quality of grape (Vitis vinifera L. cv. Gizel Uzum). International Journal of Agriculture and Crop Sciences. 5(23); 2890-2898. 2013.

37.Cai, C., X. Li and K.S. Chen. Acetylsalicylic acid alleviates chilling injury of postharvest loquat (Eriobotrya japonica Lindl.) fruit, Eur. Food Res. Technol., 223: 533-539.2006. 